\title{
Isolation of a DNA Plasmid in the Fungus Rhizoctonia solani
}

\author{
By T. HASHIBA, ${ }^{*}$ Y. HOMMA, ${ }^{2}$ M. HYAKUMACHI ${ }^{3}$ AND I. MATSUDA ${ }^{1}$ \\ ${ }^{1}$ National Institute of Agricultural Sciences, Yatabe, Ibaraki-ken 305, Japan \\ ${ }^{2}$ Shikoku National Agricultural Experiment Station, Kagawa, Japan \\ ${ }^{3}$ Hokkaido University, Sapporo, Japan
}

(Received 8 December 1983; revised 13 March 1984)

\begin{abstract}
A DNA plasmid, designated pRS64, was detected in three isolates of anastomosis group 4 (AG4) of Rhizoctonia solani Kühn by biophysical methods. The plasmid was a linear double-stranded DNA with a molecular weight of $1.68 \pm 0.06 \times 10^{6}$ or $2617 \pm 87 \mathrm{bp}$. Weakly pathogenic isolates of $R$. solani, $1668 \mathrm{RI}-1,1271 \mathrm{RI}-64$ and 1272 RI-1, which showed abnormally slow growth, contained the plasmids, but pathogenic isolates, 1668, 1271 and 1272, showing normal growth, contained no detectable plasmid DNA.
\end{abstract}

\section{INTRODUCTION}

Viruses or virus-like particles have been reported in over 30 species of plant-pathogenic fungi (Hollings, 1982). In several cases, the effects of the viruses on pathogenicity of the fungus have been studied (Castanho \& Butler, 1978a, b; Day et al., 1977; Dodds, 1980; Hollings, 1978). Several reports have been published on degenerative diseases of fungi, including plantpathogenic fungi, in which a few species have been reported to exhibit degenerative-type symptoms. Castanho \& Butler $(1978 a, b)$ and Castanho et al. (1978) reported that a degenerative decline occurred in a severely diseased isolate of Rhizoctonia solani that has been associated with an assortment of double-stranded (dsRNA) segments of three different sizes $(2.2,1.5$ and $1.1 \mathrm{MDal}$ ), but so far no virus particles have been observed. Furthermore, Endothia parasitica contained dsRNA that was transmissible by hyphal anastomosis, accompanied by poor growth in culture and diminished pathogenicity (Day et al., 1977; Dodds, 1980).

In the present paper we report the detection of a linear DNA molecule in three weakly pathogenic isolates of $R$. solani by biophysical methods.

\section{METHODS}

Organisms. The three strongly pathogenic isolates of anastomosis group 4 (AG-4) of Rhizoctonia solani Kühn used in this study were obtained from soil infested by $R$. solani 1978 and 1980, as described previously (Homma $e t$ al., 1981; Hyakumachi et al., 1983a). The weakly pathogenic isolates 1668 RI-1, 1271 RI-64 and 1272 RI-1 were isolated from soil initially infested with the strongly pathogenic isolates 1668,1271 and 1272 of $R$. solani, and planted weekly to successive crops of radishes. The pathogenicity of these isolates had been previously determined by Hyakumachi et al. (1983a) and Homma et al. (1983). Weakly pathogenic isolates of $R$. solani showed abnormally slow growth and low virulence to radish seedlings, whereas pathogenic isolates showed normal growth and high virulence to radish seedlings. Cultures were maintained on potato/sucrose agar.

Cultures. For mass mycelial propagation, isolates were grown in potato liquid medium containing polypeptone without shaking. Then 50 Petri dishes, each containing $20 \mathrm{ml}$ potato/sucrose agar liquid medium, were inoculated with $1 \mathrm{ml}$ of a culture homogenate of each isolate (previously grown for $1-2 \mathrm{~d}$ in potato/sucrose liquid medium). The mycelium grown for $15 \mathrm{~h}$ was harvested on a $150 \mu \mathrm{m}$ steel sieve, and washed with distilled water.

Protoplast formation. Protoplasts from $R$. solani were prepared using a modified method of Hashiba (1982) and Hashiba \& Yamada (1982). Mycelium ( $1 \mathrm{~g}$ fresh weight) was suspended in $10 \mathrm{ml}$ of the enzyme mixture (cellulase 'onozuka' RS $20 \mathrm{mg} \mathrm{ml}^{-1}$, macerozyme R-10 $5 \mathrm{mg} \mathrm{ml}^{-1}$ and $\beta$-glucuronidase $0.06 \mathrm{ml} \mathrm{ml}^{-1}$ ) in a $100 \mathrm{ml}$ Erlenmeyer flask. The flask was placed on a reciprocal shaker at 75 strokes $\min ^{-1}$ at $34^{\circ} \mathrm{C}$ for $3 \mathrm{~h}$. The culture was filtered through a $150 \mu \mathrm{m}$ steel sieve to remove mycelial fragments, and the filtrate was centrifuged at least twice at 
$700 \mathrm{~g}$ for $5 \mathrm{~min}$ to remove the enzymes. Intact protoplasts were further separated from mycelial fragments and cell debris by an aqueous two-phase system which consisted of $0.6 \mathrm{M}$-sucrose $/ 0.6 \mathrm{M}$-mannitol.

Preparation of DNA from protoplasts. All manipulations were carried out at room temperature unless otherwise indicated. Protoplasts were transferred to a $1.5 \mathrm{ml}$ Eppendorf tube and centrifuged for $5 \mathrm{~min}$. The supernatant was carefully removed with a fine-tip aspirator. Plasmid DNA was detected by a modification of the procedure of Birnboim \& Doly (1979). The final DNA extract $(40 \mu \mathrm{l})$ was mixed with $8 \mu \mathrm{l}$ of a staining solution [35\% Ficoll $(w / v)$ and $0.05 \%(w / v)$ bromophenol blue] and analysed by agarose gel electrophoresis. DNA bands were visualized under UV ( $365 \mathrm{~nm}$ ) light. Each DNA band was separated from gels by an electrophoretic elution procedure and purified by phenol treatment and alcohol precipitation.

Electrophoresis. The DNA samples were subjected to $1 \%$ agarose gel electrophoresis. The gel was stained with ethidium bromide and fluorescent bands of DNA were photographed under long-wave UV light. The molecular sizes of DNA were estimated after calibration of the electrophoretic mobility of phage $\lambda$ DNA fragments digested with HindIII.

Electron microscopy. A DNA protein monolayer for electron microscopy was prepared by the formamide and cytochrome $c$ techniques as described by Kleinschmidt (1968). Double-strand pBR322 DNA (4361 kb) served as an internal length standard.

Special chemicals. Macerozyme R-10 from Rhizopus sp. and cellulase 'onozuka' RS from Trichoderma viride were obtained from Yakult Biochemical Co., Nishinomiya, Japan, and $\beta$-glucuronidase type H-2 from Helix pomatia; pancreatic ribonuclease heated at $80^{\circ} \mathrm{C}$ for $10 \mathrm{~min}$ and $\mathrm{RNAase}-$ free deoxyribonuclease were obtained from Sigma.

\section{RESULTS}

\section{Detection of plasmid DNA}

Alkaline lysates of protoplasts obtained from various isolates of $R$. solani were examined for the existence of plasmids by agarose gel electrophoresis. In investigating three weakly pathogenic isolates of $R$. solani, 1668 RI-1, 1271 RI-64 and 1272 RI-1, a plasmid-like DNA band was found in addition to the top band corresponding to nuclear and mitochondrial DNAs (Fig. $1 a$, lanes 2-4). No plasmid-like DNA was detected among three strongly pathogenic isolates of $R$. solani, 1668, 1271 and 1272 (Fig. $1 a$, lanes 5-7). All bands disappeared when treated with DNAase (Fig. $1 b$, lane 4) but were resistant to the RNAase treatment (Fig. $1 b$, lane 3). From these results, the DNA band found in addition to nuclear and mitochondrial DNA bands is interpreted as plasmid DNA and designated pRS64. The plasmid band was separately isolated from a number of gels by an electrophoretic elution procedure for further study.

\section{Structure and size of plasmid DNA}

In electron microscopy, the pRS64 plasmid fractions in isolates $1688 \mathrm{RI}-1,1271 \mathrm{RI}-64$ and 1272 RI-1 purified from gels were found to consist of homogeneous populations of linear DNA (Fig. $2 a-c$ ). No circular molecules as observed for the marker pBR322 were detected. The size of the linear molecules of plasmids was determined by measuring their length relative to the length of open-circular pBR322, which was used as an internal standard in the same spreading. The ratio of the plasmid DNA length in the three weakly pathogenic isolates to $\mathrm{pBR} 322$ DNA length was $0.60 \pm 0.02$ (mean of 106 molecules \pm SD). The length of the DNA was $2617 \pm 87 \mathrm{bp}$, assuming a length of $4361 \mathrm{bp}$ for pBR322. The DNA was shown to have a molecular weight of $1.68 \pm 0.06 \times 10^{6}$ by this method.

The molecular weight of plasmid DNA was also estimated on the basis of mobility by electrophoresis in comparison with linear DNA fragments obtained from HindIII digestion of DNA. When the logarithm of the molecular weight was plotted against distance migrated, the plasmid DNA in the three weakly pathogenic isolates was shown to have a molecular weight of $1.70 \pm$ $0.02 \times 10^{6}$ (mean of 30 determinations). The value was in close agreement with the size estimated by electron microscopy, and evidence of the linear structures of the pRS64 plasmids.

\section{DISCUSSION}

We searched for plasmids among three weakly pathogenic isolates of $R$. solani and found one novel DNA plasmid, pRS64 (molecular weight $1.68 \pm 0.06 \times 10^{6}$ ). These molecules did not 

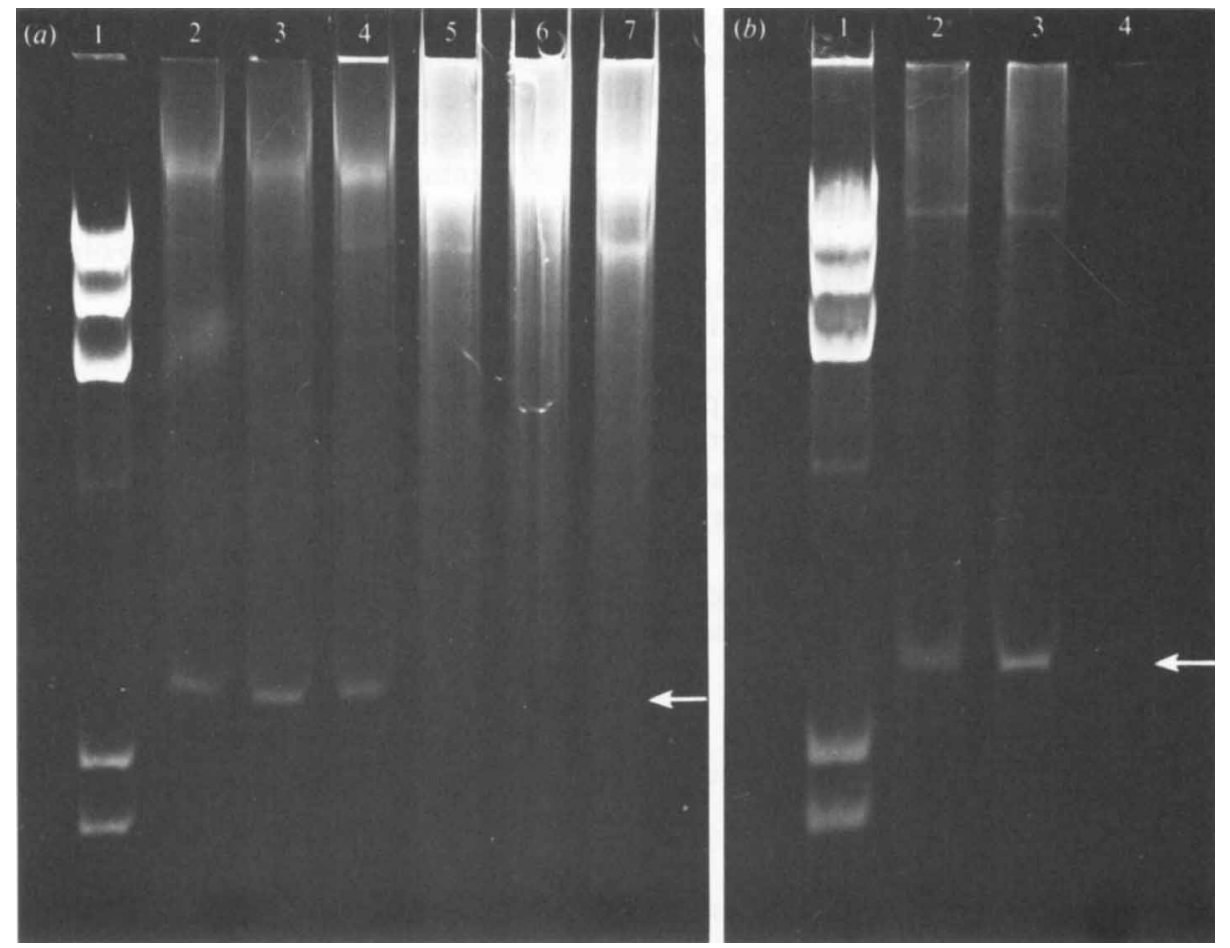

Fig. 1. (a) Electrophoresis of DNA extract from six isolates of $R$. solani in $1 \%$ agarose gels. Lane 1 , $H$ indIII fragments of phage $\lambda$ DNA; lane 2, DNA from isolate $1668 \mathrm{RI}-1$; lane 3, DNA from isolate 1271 RI-64; lane 4, DNA from isolate 1272 RI-1; lane 5, DNA from isolate 1668; lane 6, DNA from isolate 1271; lane 7, DNA from isolate 1272. The arrow indicates plasmid DNA. (b) Agarose gel electrophoresis of DNA isolated from isolate 1271 RI-64 of $R$. solani. Lane 1, Hindlll fragments of phage $\lambda$ DNA; lane 2, DNA without treatment; lane 3, DNA digested with $10 \mu \mathrm{g}$ RNAase (bovine pancreatic ribonuclease A) per $\mathrm{ml}$ for $1 \mathrm{~h}$ at $37^{\circ} \mathrm{C}$; lane 4, DNA digested with $10 \mu \mathrm{g}$ DNAase (RNAase-free deoxyribonuclease) per $\mathrm{ml}$ for $1 \mathrm{~h}$ at $37^{\circ} \mathrm{C}$. The arrow indicates plasmid DNA.
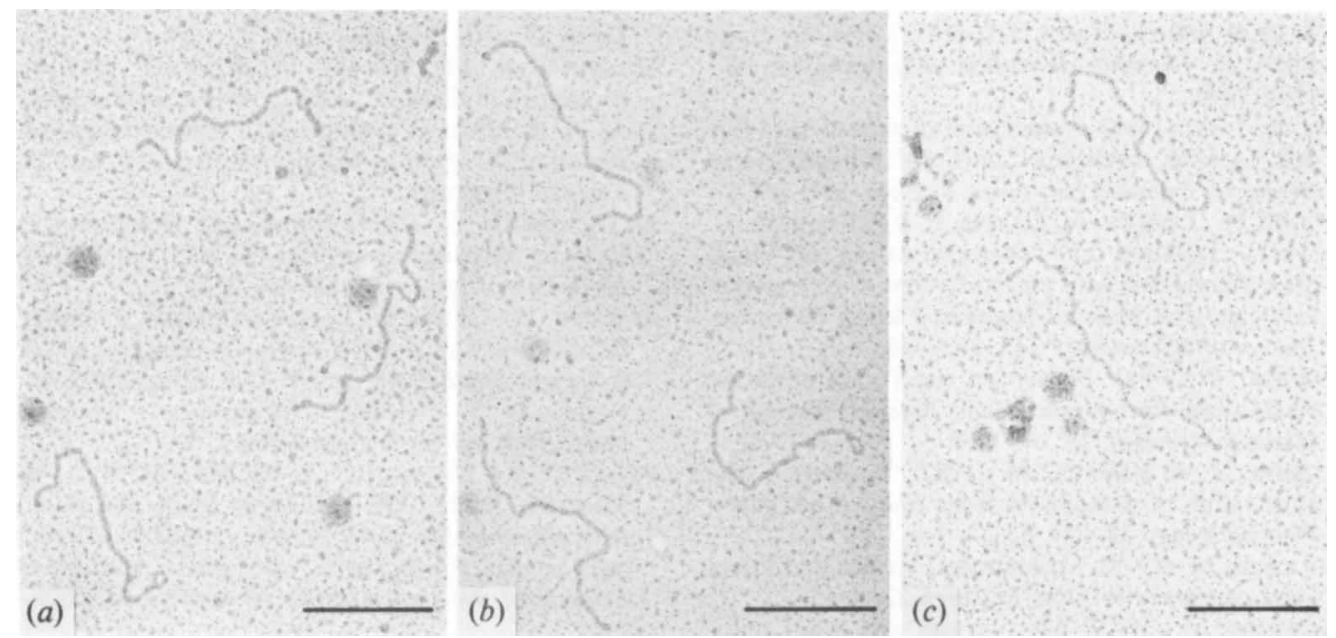

Fig. 2. Electron micrographs of DNA molecules from three weakly pathogenic isolates of $R$. solani by the formamide and cytochrome $c$ technique. (a) DNA molecule from isolate $1668 \mathrm{RI}-1$; (b) DNA molecule from isolate $1271 \mathrm{RI}-64$; (c) DNA molecule from isolate $1272 \mathrm{RI}-1$. Bars represent $1 \mathrm{~kb}$. 
sediment with mitochondria, and they were resistant to RNAase but sensitive to DNAase. From these results, the plasmid is interpreted as a DNA plasmid, and it is designated pRS64. This plasmid, characterized by a linear structure, is unlike the circular structure of bacterial plasmids and the $2 \mu \mathrm{m}$ DNA found in yeast. Weakly pathogenic cultures containing plasmids grew poorly and produced oxalic acid in the medium (Hyakumachi et al., 1983a,b). In Zea mays, both circular and linear DNA molecules of comparable size have been reported (Pring et al., 1977). Linear DNA molecules also have been described in a few eukaryotic micro-organisms, e.g. the yeast Kluyveromyces lactis (Gunge et al., 1981).

Rhizoctonia solani isolates $1271 \mathrm{RI}-64,1272 \mathrm{RI}-1$ and $1668 \mathrm{RI}-1$ were found to show decreased pathogenicity. All of the three pathogenic isolates of $R$. solani lacked the pRS64 plasmid. Thus, it seems highly probable that the weakly pathogenic character of $R$. solani isolates may be under the control of the pRS64 plasmid. Martini et al. (1978) have reported that a single band of covalently closed circular DNA was extracted from two different races of $R$. solani differing only in their host specificities. Each of the single bands migrated at consistently different rates on the gels. The fact that the two bands were different, and paralleled the difference in phytopathogenicity of the two strains, suggested that there is a possible relationship between the presence of extrachromosomal DNA and phytopathogenicity.

The authors wish to sincerely thank Professor T. Ishikawa, University of Tokyo, Japan, for helpful suggestions and encouragement; Dr M. Yamada and Dr H. Yaegashi of the National Institute of Agricultural Sciences for kind help; and Dr R. C. Staples, Boyce Thompson Institute, Ithaca, NY, USA, for critically reading the manuscript.

\section{REFERENCES}

Birnbolm, H. C. \& Doly, J. (1979). A rapid alkaline extraction procedure for screening recombinant plasmid DNA. Nucleic Acids Research 7, 1513-1523.

Castanho, B. \& Butler, E. E. (1978a). Rhizoctonia decline: a degenerative disease of Rhizoctonia solani. Phy'topathology 68, 1505-1510.

Castanho, B. \& Butler, E. E. (1978b). Rhizoctonia decline: studies on hypovirulence and potential use in biological control. Phytopathology 68, 1511-1514.

Castanho, B., Butler, E. E. \& Shepherd, R. J. (1978). The association of double-strand RNA with Rhizoctonia decline. Phytopathology 68, 1515-1519.

Day, P. R., Dodds, J. A., Elliston, J. E., JAYNes, R. A. \& Anagnostakis, S. L. (1977). Double-strand RNA in Endothia parasitica. Phytopathology 67, 1393-1396.

DodDs, J. A. (1980). Association of type 1 viral-like dsRNA with club-shaped particles in hypovirulent strains of Endothia parasitica. Virology 107, 1-12.

Gunge, N., Tamaru, A., Ozawa, F. \& Sakaguchi, K. (1981). Isolation and characterization of linear deoxyribonucleic acid plasmids from Kluyveromyces lactis and the plasmid associated killer character. Journal of Bacteriology 145, 382-390.

HASHIBA, T. (1982). Formation and fusion of protoplasts from Rhizoctonia solani. Japanese Journal of Medical Mycology 23, 143-150.

HaShibA, T. \& YAMADA, M. (1982). Formation and purification of protoplasts from Rhizoctonia solani. Phytopathology 72, 849-853.

Hollings, M. (1978). Mycoviruses: viruses that infect fungi. Advances in Virus Research 22, 3-53.

Hollings, M. (1982). Mycoviruses and plant pathology. Plant Disease 66, 1106-1112.
Homma, Y., Yamashita, Y., Kubo, T. \& Ishil, M. (1981). Differences among isolates in decline of Japanese radish damping-off in the soil reinoculated with Rhizoctonia solani Kühn. Annals of the Phytopathological Society of Japan 47, 388 (abstract).

Homma, Y., Оhвi, Y. \& Katsube, T. (1983). Suppresive factors to Japanese radish damping-off in the soil reinoculated with Rhizoctonia solani. Annals of the Phytopathological Society of Japan 49, 388 (abstract).

Hyakumachi, M., Homma, Y. \& Ui, T. (1983a). Properties of diseased isolates of Rhizoctonia solani AG-4. Annals of the Phytopathological Society of Japan 49, 120-121 (abstract)

Hyakumachi, M., Нomma, Y. \& UI, T. (1983b). Properties of diseased isolates of Rhizoctonia solani AG-4 II. Cross protection with diseased isolates. Annals of the Phytopathological Society of Japan 49, 374-375 (abstract).

KLEINSCHMIDT, A. (1968). Monolayer techniques in electron microscopy of nucleic acid molecules. Methods in Enzymology 12, 361-377.

Martini, G., Grimaldi, G. \& Guardiola, J. (1978). Extrachromosomal DNA in phytopathogenic fungi. In Genetic Engineering, pp. 197-200. Edited by H. W. Boyer \& S. Nicosia. Amsterdam: Elsevier/ North-Holland Biomedical Press.

Pring, D. R., I.evings, C. S. III, Hu, W. W. L. \& Timothy, D. H. (1977). Unique DNA associated with mitochondria in the ' $S$ '-type cytoplasm of malesterile maize. Proceedings of the National Academy of Sciences of the United States of America 74, 2904 2908. 